\title{
THE ANEMIA OF THERMAL INJURY. I. STUDIES OF PIGMENT EXCRETION 1, 2
}

\author{
By G. WATSON JAMES, III, ${ }^{3}$ OLIVER J. PURNELL, 4 ANd EVERETT I. EVANS, 5 \\ WITH THE TECH NICAL ASSISTANCE OF VIVIAN WILKERSON AND \\ ANNE ANDERSON
}

\begin{abstract}
(From the Laboratory for Clinical Investigation, Department of Medicine, and the Surgical Research Laboratory, Department of Surgery, Medical College of Virginia, Richmond)
\end{abstract}

(Submitted for publication September 7, 1950; accepted, November 6, 1950)

Our interest in the metabolism of hemoglobin in patients with thermal injury was stimulated by early observations that $(a)$ in spite of multiple whole blood transfusions anemia often developed rapidly in the first 96 hours after injury, and (b) in the protracted convalescence of a patient with only a small burn, moderate anemia inevitably ensued. The latter was exceptionally refractory to all except replacement therapy. With these two facts in mind we have undertaken our present study of the burn patient in an attempt to answer the following questions: (1) to what extent does hemolysis occur, and (2) what information about the anemia of the protracted convalescent stage might a continuous investigation of heme metabolism give us?

Previous work on the same general problem has already been presented by Moore, Peacock, Blakeley, and Cope (1), who demonstrated an increased excretion of urobilinogen in the urine of four patients and an increased excretion in the feces in one patient. Similarly, the British workers, Anderson and Semeonoff (2), described increased excretion of urinary urobilinogen. Others have pointed out the potentiality of increased osmotic fragility and plasma hemolysis $(3,4)$ early in the post-burn period as well as agglutination and "sludging" of the red cells (5) in the peripheral circulation removed from the site of the injury.

1 Presented in part before the Clinical Congress, American College of Surgeons, October 16-23, 1949, Chicago, Illinois.

2 Supported by grants to the Surgical Research Laboratory, Department of Surgery, from the Medical Research and Development Board, Department of the Army (Project: S.F. No. W-49-007-MD-411).

3 Markle Scholar in Medical Sciences; formerly, Postdoctorate Research Fellow of National Institutes of Health.

- Surgical Research Fellow.

5 Director of Surgical Research Laboratory.
Cartwright and his associates have presented several papers discussing some of the metabolic aspects of the anemia of chronic sepsis, and give data showing low serum iron, elevated serum copper and increased urinary coproporphyrin excretion (6). A few studies are available, notably those of Saifi and Vaughan $(7,8)$, in which estimations of the urobilinogen excretion in the urine and feces in chronic sepsis have been made. In our experience bacterial contamination and growth on the burned area is always present after the first dressing of third degree burns.

In the investigation of an anemia which appears suddenly over a period of a few days, it would seem of some importance to estimate the amount of the end products of hemoglobin catabolism. The correlation of the amount of hemoglobin end products, as urobilinogen, with the total number of grams of circulating hemoglobin has been discussed by Miller, Singer, and Dameshek (9) and others as the hemolytic index, and can serve as a rather reliable method of estimating intravascular hemolysis. Moore and his colleagues (1) in their review mention the initial hemolytic phase of burns but only support this observation with one case with fecal urobilinogen study. We believe the urine urobilinogen may have a different interpretation than that described.

\section{METHODS AND MATERIAL}

Seventeen burn patients admitted to the Burn Service of the Department of Surgery at the Medical College of Virginia were selected for study. The burns were usually of the free fire type caused by kerosene explosions in wood stoves and by blazing clothing. Immediately after admission the patients were started on study with an initial hemogram, a blood volume determination, and a continuous collection of all urine and feces. Subsequent blood studies were performed as indicated. Treatment in all the cases was essentially the same, employing pres- 
TABLE I

\begin{tabular}{|c|c|c|c|c|c|c|c|c|}
\hline & \multirow{2}{*}{ Patient } & \multirow{2}{*}{ Age } & \multirow{2}{*}{ Sex } & \multirow{2}{*}{ Race } & \multicolumn{2}{|c|}{$\begin{array}{l}\text { Amount of burn } \\
\text { in per cent }\end{array}$} & \multirow{2}{*}{ Cause } & \multirow{2}{*}{ Result } \\
\hline & & & & & $\begin{array}{l}\text { Third } \\
\text { degree }\end{array}$ & Total & & \\
\hline $\begin{array}{l}\text { Group I } \\
0 \text { to } 10 \%\end{array}$ & $\begin{array}{l}\text { C. W. } \\
\text { A. D. } \\
\text { R. G. } \\
\text { G. C. } \\
\text { J. B. } \\
\text { W. B. }\end{array}$ & $\begin{array}{l}17 \\
13 \\
28 \\
10 \\
35 \\
11\end{array}$ & $\begin{array}{l}\mathbf{M} \\
\mathbf{F} \\
\mathbf{M} \\
\mathbf{M} \\
\mathbf{M}\end{array}$ & $\begin{array}{l}\mathbf{W} \\
\mathbf{W} \\
\mathbf{W} \\
\mathbf{W} \\
\mathbf{N} \\
\mathbf{N}\end{array}$ & $\begin{array}{l}0 \\
1.5 \\
2.0 \\
4.0 \\
4.0 \\
7.0\end{array}$ & $\begin{array}{l}35 \\
23 \\
12 \\
70 \\
16.5 \\
11.0\end{array}$ & $\begin{array}{l}\text { Gasoline explosion } \\
\text { Free fire } \\
\text { Electrical } \\
\text { Free fire } \\
\text { Hot water } \\
\text { Free fire }\end{array}$ & $\begin{array}{l}\mathrm{R}^{*} \\
\mathrm{R} \\
\mathrm{R} \\
\mathrm{R} \\
\mathrm{R} \\
\mathrm{R}\end{array}$ \\
\hline $\begin{array}{l}\text { Group II } \\
11 \% \text { to } 20 \%\end{array}$ & $\begin{array}{l}\text { B. C. } \\
\text { A. C. } \\
\text { B. R. }\end{array}$ & $\begin{array}{l}60 \\
19 \\
15\end{array}$ & $\begin{array}{l}\mathbf{M} \\
\mathbf{M} \\
\mathbf{M}\end{array}$ & $\begin{array}{l}\mathbf{W} \\
\mathbf{N} \\
\mathbf{N}\end{array}$ & $\begin{array}{l}11.5 \\
12 \\
15\end{array}$ & $\begin{array}{l}22.5 \\
17.5 \\
20\end{array}$ & $\begin{array}{l}\text { Free fire } \\
\text { Gasoline } \\
\text { Free fire }\end{array}$ & $\begin{array}{l}\mathbf{R} \\
\mathbf{R} \\
\mathbf{R}\end{array}$ \\
\hline $\begin{array}{c}\text { Group III } \\
21 \% \text { or greater }\end{array}$ & $\begin{array}{l}\text { C. T. } \\
\text { F. T. } \\
\text { J. M. } \\
\text { S. L. } \\
\text { G. L. } \\
\text { F. J. } \\
\text { O. B. }\end{array}$ & $\begin{array}{l}31 \\
33 \\
84 \\
57 \\
19 \\
20 \\
29\end{array}$ & $\begin{array}{l}\mathrm{M} \\
\mathrm{M} \\
\mathrm{M} \\
\mathrm{F} \\
\mathrm{F} \\
\mathrm{F} \\
\mathrm{F}\end{array}$ & $\begin{array}{l}\mathbf{N} \\
\mathbf{N} \\
\mathbf{N} \\
\mathbf{W} \\
\mathbf{N} \\
\mathbf{N} \\
\mathbf{N}\end{array}$ & $\begin{array}{l}30 \\
30 \\
38 \\
20 \\
51 \\
55 \\
65\end{array}$ & $\begin{array}{l}47 \\
95 \\
48 \\
70 \\
63 \\
65 \\
74.5\end{array}$ & $\begin{array}{l}\text { Free fire } \\
\text { Gasoline explosion } \\
\text { Free fire } \\
\text { Free fire } \\
\text { Free fire } \\
\text { Free fire } \\
\text { Free fire }\end{array}$ & $\begin{array}{l}D^{*} \\
D \\
D \\
D \\
D \\
D \\
D\end{array}$ \\
\hline
\end{tabular}

${ }^{*} \mathrm{R}=$ Recovered; $\mathrm{D}=$ Died.

sure bandage without debridement, parenteral antibiotics, fluids and when indicated whole blood transfusion.

The hematologic methods were those given by Wintrobe (10). Hemoglobin was measured by the alkaline hematin method in sodium carbonate on the Coleman Junior Spectrophotometer, standardized for hemoglobin by the oxygen capacity method. The urine was collected in brown glass bottles, using $5 \mathrm{Gm}$. of sodium carbonate with petroleum ether as a preservative. Feces were collected in waxed carton containers. Urine urobilinogen determinations were done on one day or two day collections, fecal urobilinogen on four day or longer collections by the quantitative method of Schwartz, Sborov, and Watson (11). We have used $200 \mathrm{mg}$. per day as the upper limit of normal for fecal urobilinogen studies since this was the highest value obtained on two normal subjects in our laboratory. This is somewhat lower than the upper limits usually described as $250 \mathrm{mg}$. per day. Total urinary coproporphyrin was determined on the Klett photofluorometer model 1040 by the method of Schwartz, Hawkinson, Cohen, and Watson (12). Standardization of our instrument was performed with coproporphyrin dimethyl ester, prepared, isolated, and purified in our laboratory from porphyria urine and urine from lead poisoned patients. Serum bilirubin (13), T-1824 plasma volume (14), and $\mathrm{P}^{22}$ red cell volume (15) were determined at intervals designed to aid us in our studies. The hemolytic index, a ratio of urobilinogen excretion per day to total circulating hemoglobin, has been described by Miller, Singer, and Dameshek (9). It is calculated in the following manner:

hemolytic index

$$
=\frac{\text { urobilinogen excretion in mg. per day } \times 100}{\text { total circulating hemoglobin in grams }} .
$$

The normal range of this index is given as 11-21.

\section{RESULTS AND DISCUSSION}

Table I presents statistical data on our patients who were arbitrarily separated into three groups based on the percentage of third degree burn as estimated by the Lund and Browder values (16). This division is as follows: Group I, 0 to 10 per cent; Group II, 11 to 20 per cent; Group III, 21 per cent or greater.

The results of the fecal urobilinogen studies should be evaluated in the light of previous experience that whole blood transfusions, particularly if the blood has been stored for more than a week, leads in some instances, not only to a slight increase in the serum bilirubin, but also an increase in fecal urobilinogen $(17,18)$. Also of considerable importance are the recent clinical studies of London (19) and his associates which indicate that at least 11 per cent of the fecal stercobilin ${ }^{6}$ in normal persons is derived from sources other than the pigment fraction of hemoglobin. To what extent increases in fecal urobilinogen (vide infra) are due to non-hemoglobin sources in our patients cannot be ascertained, and the possibility exists that tissue destruction is contributing tetrapyrrols, due to intracellular breakdown since all cells contain the ferroprotoporphyrin ring.

- The method used in this work measures both stercobilinogen and mesobilirubinogen and the result of the determination is expressed in terms of urobilinogen. 
In Group I there were three instances in which fecal urobilinogen was considered to be increased as evaluated by the hemolytic index. In two of these the increase occurred in the first week and was associated with a marked drop in the hemoglobin and increased hemolytic index. We have interpreted this to mean excessive hemolysis. Neither of these patients received transfusions on admission. J. B. (Figure 1), 4 per cent third degree burns, illustrates an example of this response. Laboratory studies indicated a sharp rise in the fecal urobilinogen and a fall in the total circulating hemoglobin of $122 \mathrm{Gm}$. The hemolytic index increased from 3.8 to 37.4 , later returning to within the accepted normal range of 11 to 21 .

In a patient with 35 per cent second degree burn (C. W.) there was evidence of a definite hemolytic phase. It would appear, therefore, that hemolysis is not entirely a question of the depth of burn.

In two instances in Group I there is a different response. A. D. (Figure 2) with 1.5 per cent third degree burn, was given a total of $430 \mathrm{Gm}$. of hemoglobin shortly after admission raising her total circulating hemoglobin from $523 \mathrm{Gm}$. to 896 $\mathrm{Gm}$., an increase of approximately 72 per cent. This gave rise to an "artificial" polycythemia. Interestingly enough, she did not show any excessive hemolysis as judged by the fecal urobilinogen studies. The hemolytic index of 10 was normal, but there was a moderate rise in the total serum bilirubin. The interpretation of this discrepancy is somewhat difficult. A possible explanation of this may be due to the difficulty in stool collection in this patient. It is noted that the fecal urobilinogen covers a period of eight days, whereas if the total amount of urobilinogen excreted during this period were computed on a three day basis, which it more nearly represents, the concentration of fecal urobilinogen in mg. per day would be correspondingly higher, and thus the hemolytic index. In addition as it has been pointed out by Ham and his associates (4), thermal

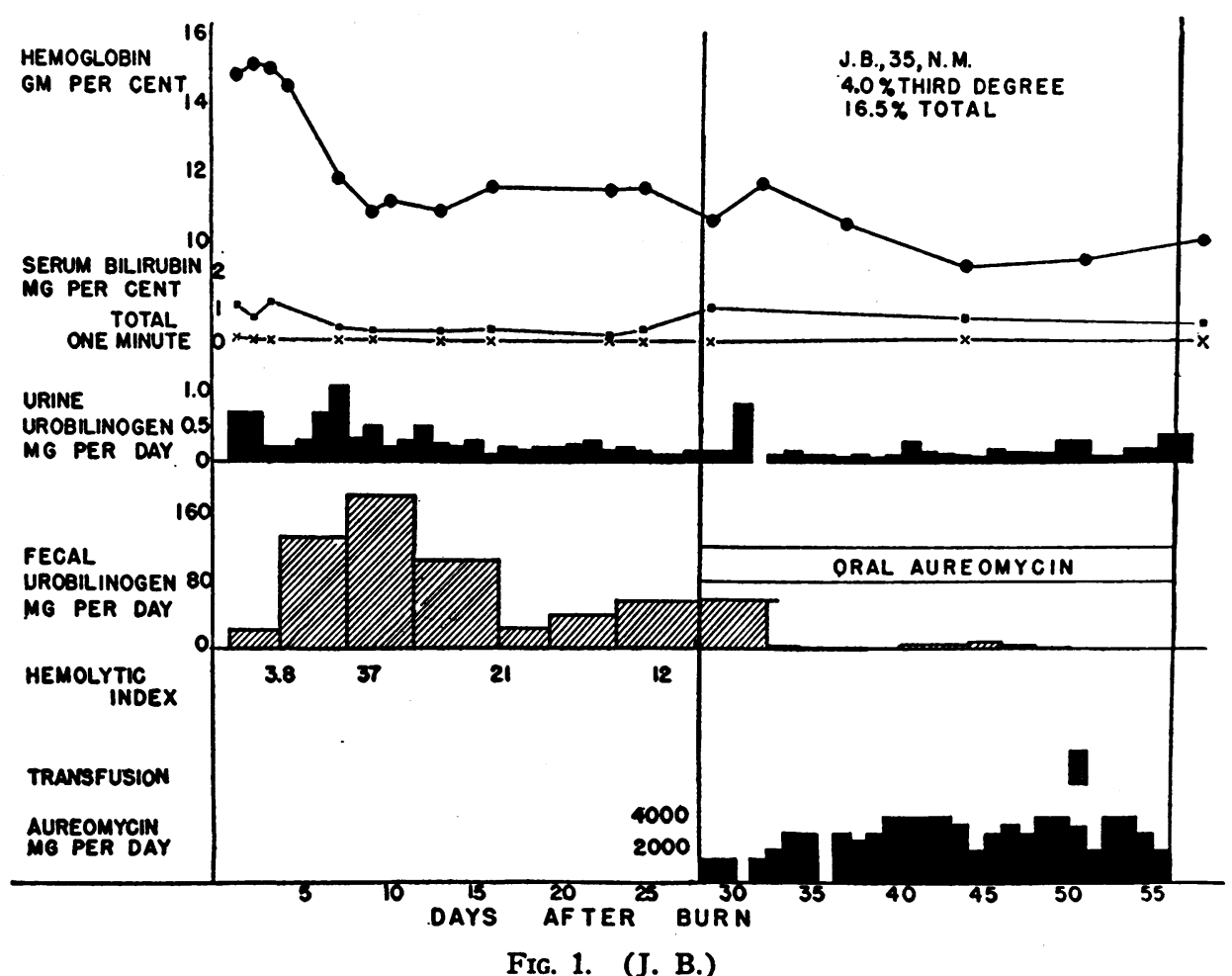

The graph demonstrates a drop in hemoglobin with a concomitant rise in the fecal urobilinogen and hemolytic index. Serum bilirubin and urine urobilinogen were unchanged. After the 28th day oral aureomycin was administered. Note the marked diminution in fecal urobilinogen output, without significant change in the urine urobilinogen. The hemolytic index after the 25th day was at the lower limit of normal and suggests decreased breakdown of heme pigments. 


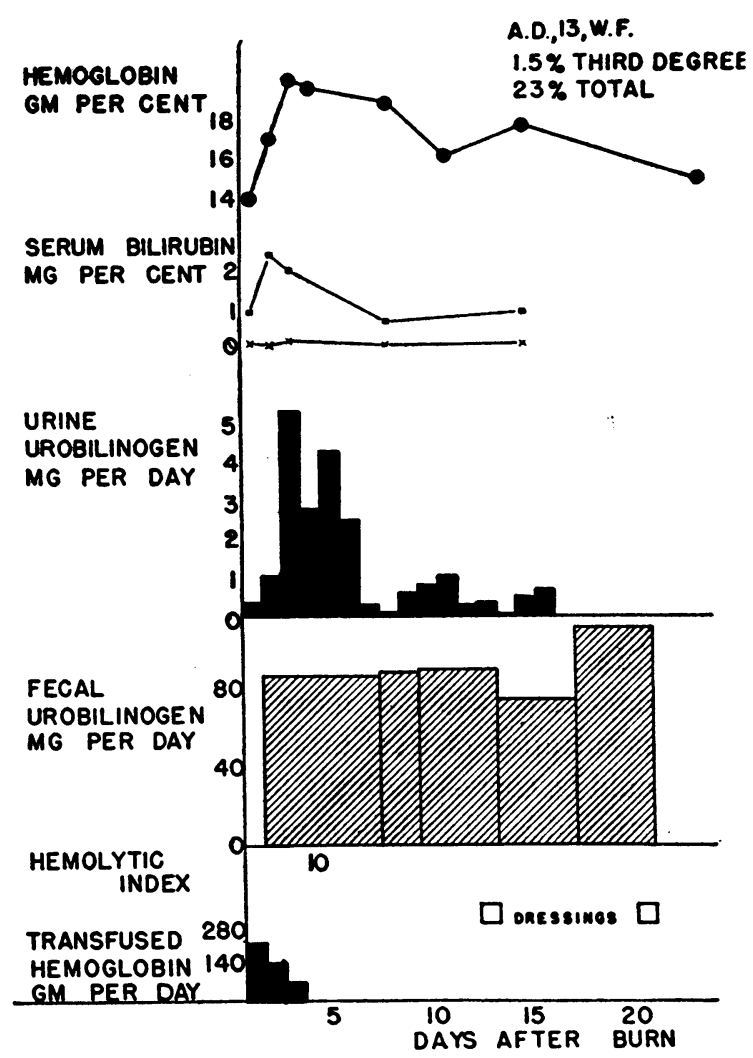

Fig. 2. (A. D.)

This patient was given $430 \mathrm{Gm}$. of hemoglobin as red cells in the first three days after admission. An artificial polycythemia was produced, but she did not exhibit any increase in the hemolytic index or fecal urobilinogen. On the third post burn day, however, the urine urobilinogen was increased, and there was a rise in the total serum bilirubin on the second day. Increased urine urobilinogen in the presence of a normal fecal urobilinogen suggests impairment of the ability of the liver to properly handle reabsorbed urobilinogen.

trauma leads to red cells potentially more fragile to osmotic and mechanical influences. The transfusion in this patient could give rise to two populations of red cells, the patient's, which are potentially subject to hemolysis, and the transfused cells, not fragile. At the same time the total circulating hemoglobin would have been raised. Hence on the basis of these speculations, if the hemolytic index were recalculated using the initial total circulating hemoglobin (prior to transfusion), the fecal urobilinogen on a three day basis, the index would have been 40 . This of course fits well with the other findings of increased indirect serum bilirubin, and the data on the subsequent patients. The other patient who showed a different response was a youth of 10 years with a 4 per cent third degree burn. Although blood volume studies were not done, he did not show a significant rise in the fecal urobilinogen until the 10th day, when the fecal urobilinogen rose to $165 \mathrm{mg}$. per day.

In Group II are those with third degree burns covering from 11 to 20 per cent of the body surface. The fecal urobilinogen studies are altered by the use of oral or intravenous aureomycin, which will be discussed below.

In the severe group of burns, all of whom expired, there were marked increases in the fecal urobilinogen. Stools could not be collected in all instances but in those patients from whom specimens were obtained increases were all greater than $500 \mathrm{mg}$. per day, which is in the accepted range of the hemolytic anemias. In one instance, we were able to follow a man, F. T. (Figure 3), with 30 per cent third degree and 95 per cent total burn for a period of 33 days. At no time did his fecal urobilinogen return to normal even during a period when no transfusions were administered, and the hemolytic indices were constantly elevated. This indicates in this particular burn that continuous hemolysis played a significant part in the mechanism of the anemia. From the graph it can be seen that there was a constant and steady decline in the hemoglobin value despite multiple transfusions.

Table II gives a composite picture of the chief results as regards the fecal urobilinogen. In so far as the fecal urobilinogen is concerned, we interpret these data in the following manner. There is usually evidence of increased hemoglobin breakdown in third degree burns of less than 7 per cent of the body surface. In larger burns there is a greatly increased breakdown of hemoglobin as judged by the high excretions of fecal urobilinogen.

The urine urobilinogen appeared to follow a fairly distinct pattern in nearly all patients in the three groups unless oral aureomycin was administered. This consisted of an early rise to abnormal values, usually within the first two or three days. In the group of severely burned patients this substance attained very marked concentrations in the urine as shown in Table II. The urine urobilinogen values are tabulated as the highest one observed during hospitalization, and the value obtained on the third day after the burn. Group III 


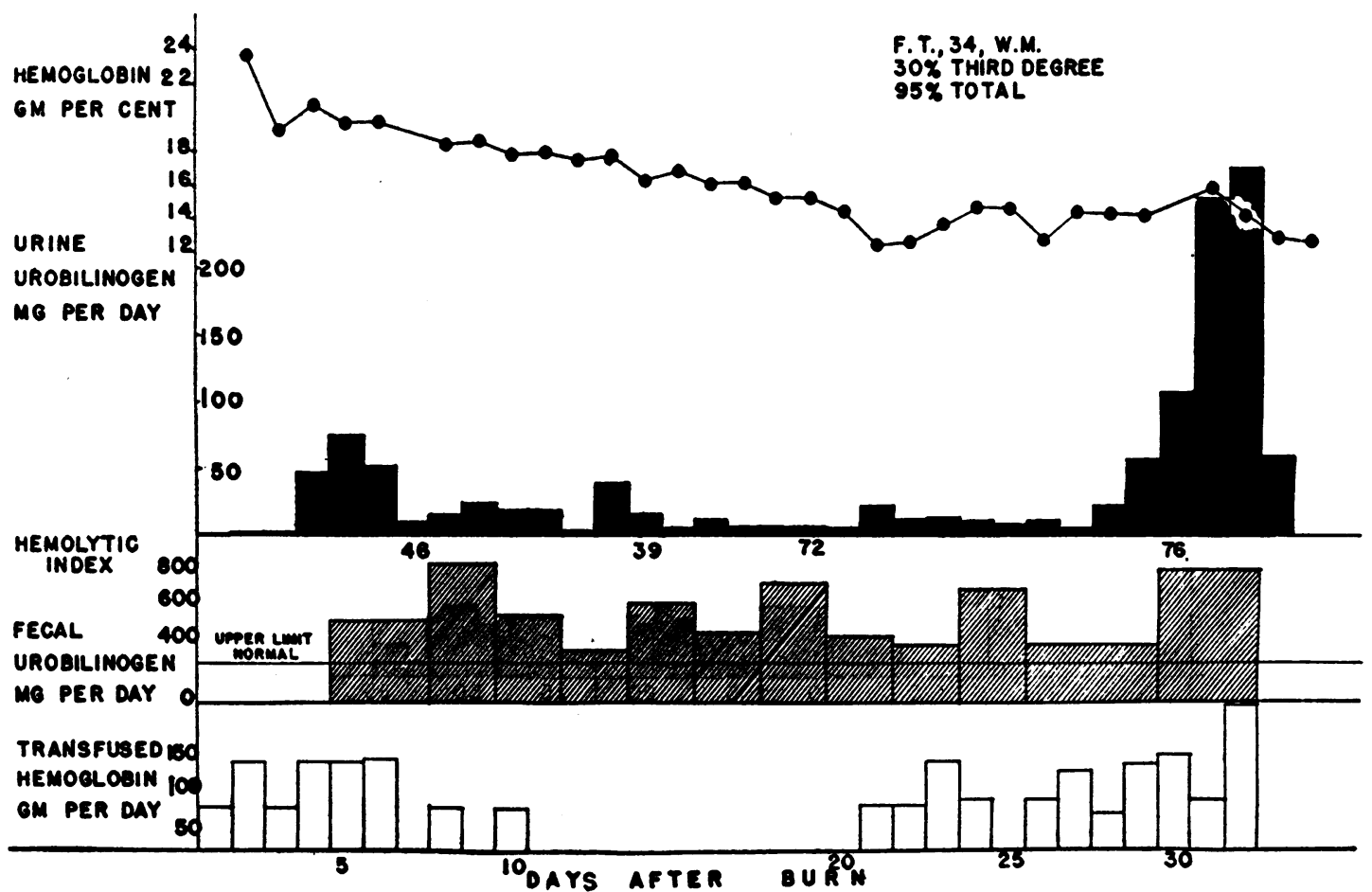

FIG. 3. (F. T.)

This patient with a severe burn demonstrated continuous and marked excretion of fecal urobilinogen and enormous increase in the urine urobilinogen immediately after injury and just before death. Despite daily transfusions except between the 11th and 20th days his hemoglobin dropped steadily, likewise during this same period the fecal urobilinogen remained elevated, and the hemolytic index was continuously increased.

TABLE II

Urine and fecal urobilinogen, hemolytic index, and serum bilirubin

\begin{tabular}{|c|c|c|c|c|c|c|c|c|c|c|c|}
\hline & \multirow{2}{*}{ Patient } & \multicolumn{2}{|c|}{ Amount of burn } & \multicolumn{2}{|c|}{$\begin{array}{l}\text { Urine urobilinogen } \\
\text { (mg. per day) }\end{array}$} & \multicolumn{2}{|c|}{ Fecal urobilinogen } & \multicolumn{2}{|c|}{ Serum bilirubin } & \multirow{2}{*}{$\begin{array}{c}\text { Hemolytic } \\
\text { index }\end{array}$} & \multirow{2}{*}{ Aureomycin } \\
\hline & & $\begin{array}{l}\text { Third } \\
\text { degree }\end{array}$ & Total & Highest & $\begin{array}{l}\text { Third day } \\
\text { post burn }\end{array}$ & $\begin{array}{c}\text { (mp. per } \\
\text { day) }\end{array}$ & $\begin{array}{l}\text { Poet burn } \\
\text { day }\end{array}$ & $1^{\prime}$ & Total & & \\
\hline Group I & $\begin{array}{l}\text { C. W. W. } \\
\text { A. D. } \\
\text { R. G. } \\
\text { G. C. } \\
\text { J. B. } \\
\dot{W} . \text { B. }\end{array}$ & $\begin{array}{c}0 \\
1.5 \\
3.0 \\
4.0 \\
4.0 \\
7.0\end{array}$ & $\begin{array}{c}35 \\
33 \\
12 \\
70 \\
16.5 \\
7.0\end{array}$ & $\begin{array}{c}18 \\
5.4 \\
32.0 \\
8.2 \\
1.2 \\
20\end{array}$ & $\begin{array}{r}18 \\
5.4 \\
11.0 \\
1.5 \\
0.3 \\
3.4\end{array}$ & $\begin{array}{r}300 \\
90 \\
215 \\
90 \\
180 \\
150\end{array}$ & $\begin{array}{l}6 \\
6 \\
6 \\
4 \\
8 \\
4\end{array}$ & $\begin{array}{l}0.12 \\
0.2 \\
0.2 \\
0.1 \\
0.4\end{array}$ & $\begin{array}{l}2.4 \\
2.4 \\
0.8 \\
1.1 \\
0.85\end{array}$ & $\begin{array}{c}34.2 \\
10.1 \\
- \\
- \\
37.4 \\
49.7\end{array}$ & $\begin{array}{l}\text { No } \\
\text { No } \\
\text { No } \\
\text { No } \\
\text { No } \\
\text { No }\end{array}$ \\
\hline$\underset{\text { II }}{\text { Group }}$ & $\begin{array}{l}\text { A. C. } \\
\text { B. C. } \\
\text { B. R. }\end{array}$ & $\begin{array}{l}11.5 \\
12.0 \\
15.0\end{array}$ & $\begin{array}{l}22.5 \\
17.5 \\
20\end{array}$ & $\begin{array}{c}42 \\
0.2 \\
6.0\end{array}$ & $\begin{array}{r}37.0 \\
0.1 \\
6.0\end{array}$ & $\begin{array}{r}\overline{0.6}^{*} \\
10.6\end{array}$ & $\begin{array}{l}\overline{2} \\
4\end{array}$ & $\begin{array}{l}\overline{0.32} \\
0.16\end{array}$ & $\begin{array}{l}\overline{4.06} \\
0.23\end{array}$ & E & $\begin{array}{l}\text { No } \\
\text { Yes } \\
\text { Yes (I.V.) }\end{array}$ \\
\hline Group & $\begin{array}{l}\text { C. T. } \\
\text { F. T. } \\
\text { J. M. } \\
\text { S. L. } \\
\text { G. L. } \\
\text { F. J. } \\
\text { O. B. }\end{array}$ & $\begin{array}{l}30 \\
30 \\
38 \\
? \\
51 \\
55 \\
65\end{array}$ & $\begin{array}{l}42 \\
95 \\
48 \\
70 \\
63 \\
65 \\
75\end{array}$ & $\begin{array}{c}250 \\
275 \\
157 \\
67 \\
32 \\
0.15 \\
0.8\end{array}$ & $\begin{array}{c}250 \\
45 \\
6.0 \\
11 \\
14 \\
0.1 \\
0.7 \ddagger\end{array}$ & $\begin{array}{c}530 \\
800 \\
582 \\
{ }_{23 \dagger}^{23} \\
6.3 \ddagger\end{array}$ & $\begin{array}{r}5 \\
5 \\
11 \\
4 \\
12 \\
3\end{array}$ & $\begin{array}{l}0.2 \\
0.6 \\
0.4 \\
1.34 \\
4.6 \\
\frac{1.7}{1.7}\end{array}$ & $\begin{array}{l}2.3 \\
1.2 \\
1.9 \\
2.17 \\
7.55 \\
\overline{5.39}\end{array}$ & $\begin{array}{l}37 \\
54 \\
- \\
-\end{array}$ & $\begin{array}{l}\text { No } \\
\text { No } \\
\text { No } \\
\text { No } \\
\text { No } \\
\text { Yes } \\
\text { Yes }\end{array}$ \\
\hline
\end{tabular}

* Diarrhea incomplete collection.

t Only $40 \mathrm{gm}$. of feces obtained.

$\mp$ No feces first nine days.

Feces lost. 


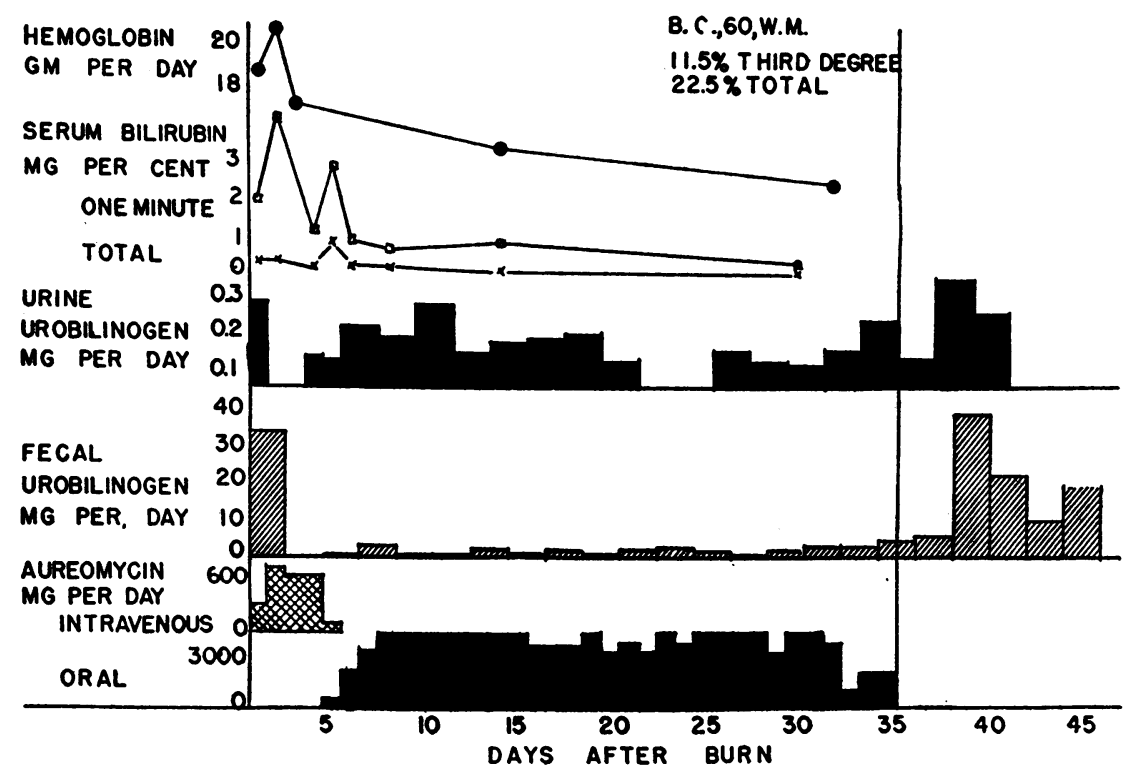

Fic. 4. (B. C.)

This demonstrates the effect of aureomycin on the fecal urobilinogen from the time of admission to the 35th hospital day. Oral aureomycin was not begun until the fifth post burn day, and the effect of intravenous aureomycin during the early period is equivocal. Note the drop in the hemoglobin and the rise in the serum bilirubin. Hemolytic indices could not be run because of the aureomycin effect.

patients show the most marked concentrations, but elevations are present in all except those receiving aureomycin and in one patient with uremia and almost complete anuria. Both Figures 2 and 3, are representative examples of the changes seen in our patients. This increased excretion of urobilinogen in the urine we interpret as evidence of early and rather marked hepatic failure, failure to properly catabolize the portal blood urobilinogen. Hence it appears in the peripheral blood and is excreted in the urine. This subject is to be dealt with more fully in a later paper.

One patient in Group I, J. B. (Figure 1); two patients in Group II, B. R. and B. C. (Figure 4) ; and two patients in the severely burned group, F. J. and O. B., were given either oral or parenteral aureomycin, or both, to observe the effect of this antibiotic on the excretion of urobilinogen in the urine and stool.

Briefly, bilirubin derived from hemoglobin is reduced by bacteria in the gastro-intestinal tract to mesobilirubinogen and stercobilinogen, both colorless compounds and conveniently grouped together with the name of urobilinogen because of an identical chromogenic reaction with Ehrlich's reagent. These are apparently entirely of enterogenous origin. Reabsorption of the urobilinogen takes place in the gut, and the liver effectively removes or catabolizes these substances in such a manner that only a small amount, up to 3 mg. per day (actually in our experience only 1.5 mg. per day), is excreted in the urine.

Sborov and his associates have already discovered the effects of aureomycin on fecal urobilinogen due to its sterilizing effect on the fecal flora (20). Our experience in finding a marked reduction is nearly the same as theirs. It is interesting to record, however, that petroleum ethersoluble Ehrlich-reacting substances, presumably tetrapyrroles, were still present. These effects with aureomycin ${ }^{7}$ are shown graphically in Figures 1 and 4.

B. R. (Table II) who suffered about 15 per cent third degree burn received both intravenous and oral aureomycin from the onset but severe nausea and vomiting make it uncertain as to how much oral aureomycin was retained. We observed that

7 The aureomycin for these studies was generously supplied by the Lederle Laboratories Division, American Cyanamid Company. 
no increase of the fecal urobilinogen occurred, but a significant rise in urine urobilinogen was evident. After aureomycin was stopped, and following a * transfusion there was a sharp rise in fecal urobilinogen. The patient B. C. (Table II) with 12 per cent third degree burn, received intravenous aureomycin initially with equivocal effect on the fecal urobilinogen. After the administration of oral aureomycin the amount of Ehrlich-reacting substances was less than $5 \mathrm{mg}$. per day. Likewise the urine urobilinogen was exceedingly low giving values of 0.1 to $0.2 \mathrm{mg}$. per day. Four days after discontinuing aureomycin the fecal urobilinogen rose to values which we have observed commonly in the convalescent phase of the moderately burned patient. The fecal urobilinogen values were extremely low in a previous patient discussed (J. B., Figure 1), ranging between 0.6 and $6 \mathrm{mg}$. per day during the time when he was receiving oral aureomycin.

As shown previously there is, in the severe group, a marked increase in the fecal urobilinogen, but in one patient, F. J., with 55 per cent third degree burn who received aureomycin, and in whom other evidence of hemolysis was present, we observed the fecal urobilinogen did not increase, and the amount of Ehrlich-reacting compounds remained essentially the same, i.e., less than $5 \mathrm{mg}$. per day and usually about $1.2 \mathrm{mg}$. per day. Likewise, the urine urobilinogen in this patient was extremely low ranging from 0.1 to $0.2 \mathrm{mg}$. per day. These observations naturally raise the question of whether the Ehrlich-reacting substance present after aureomycin is a urobilinogen, since it is rather constant even when the total amount of petroleum ether-soluble Ehrlich-reacting compounds varies over a wide range.

The total urinary coproporphyrin excretion was studied in six patients who are in the following categories. Two in Group I, three in Group II, and one in Group III. Since this determination was not begun until late in the study, it does not include all patients. There was an increased excretion of total urinary coproporphyrin in all patients studied, and it did not appear to vary with severity of the burn. In four of these, normal

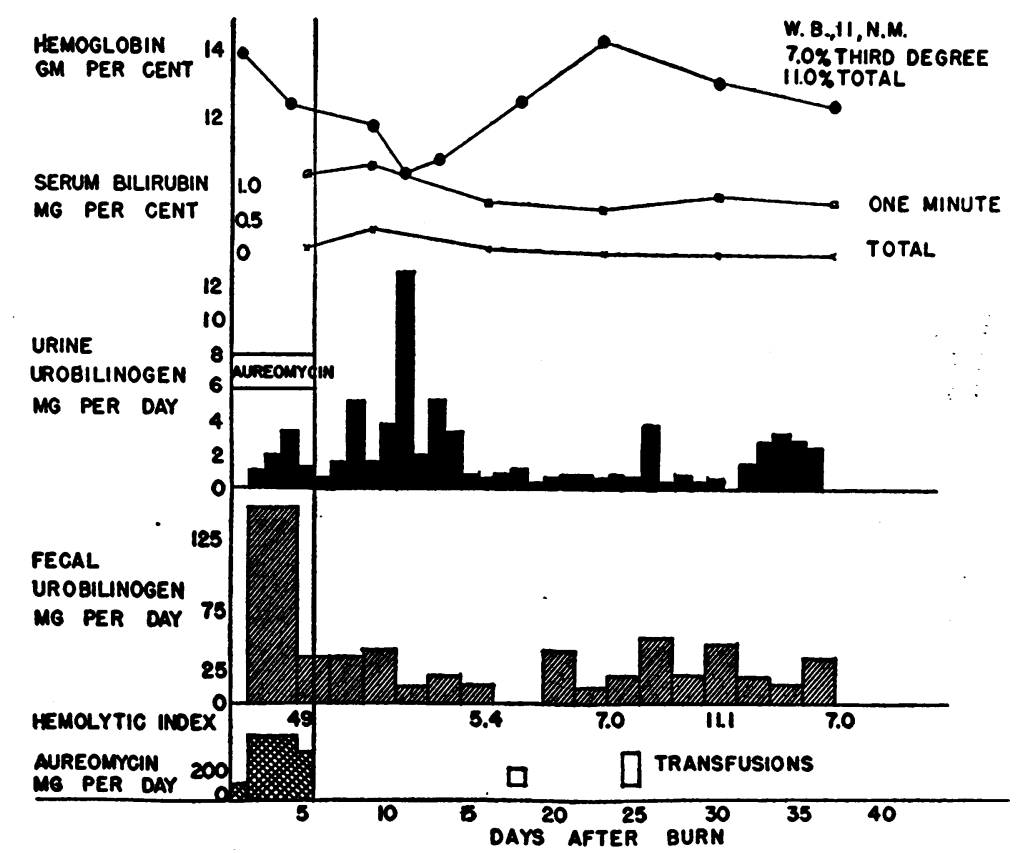

Fig. 5. (W. B.)

In this patient fecal urobilinogen was initially increased and intravenous aureomycin had no effect on either the fecal or urine urobilinogen excretion. Note the increased hemolytic index with a concomitant drop in hemoglobin. After two weeks and during convalescence the hemolytic index was low suggesting decreased heme breakdown. 


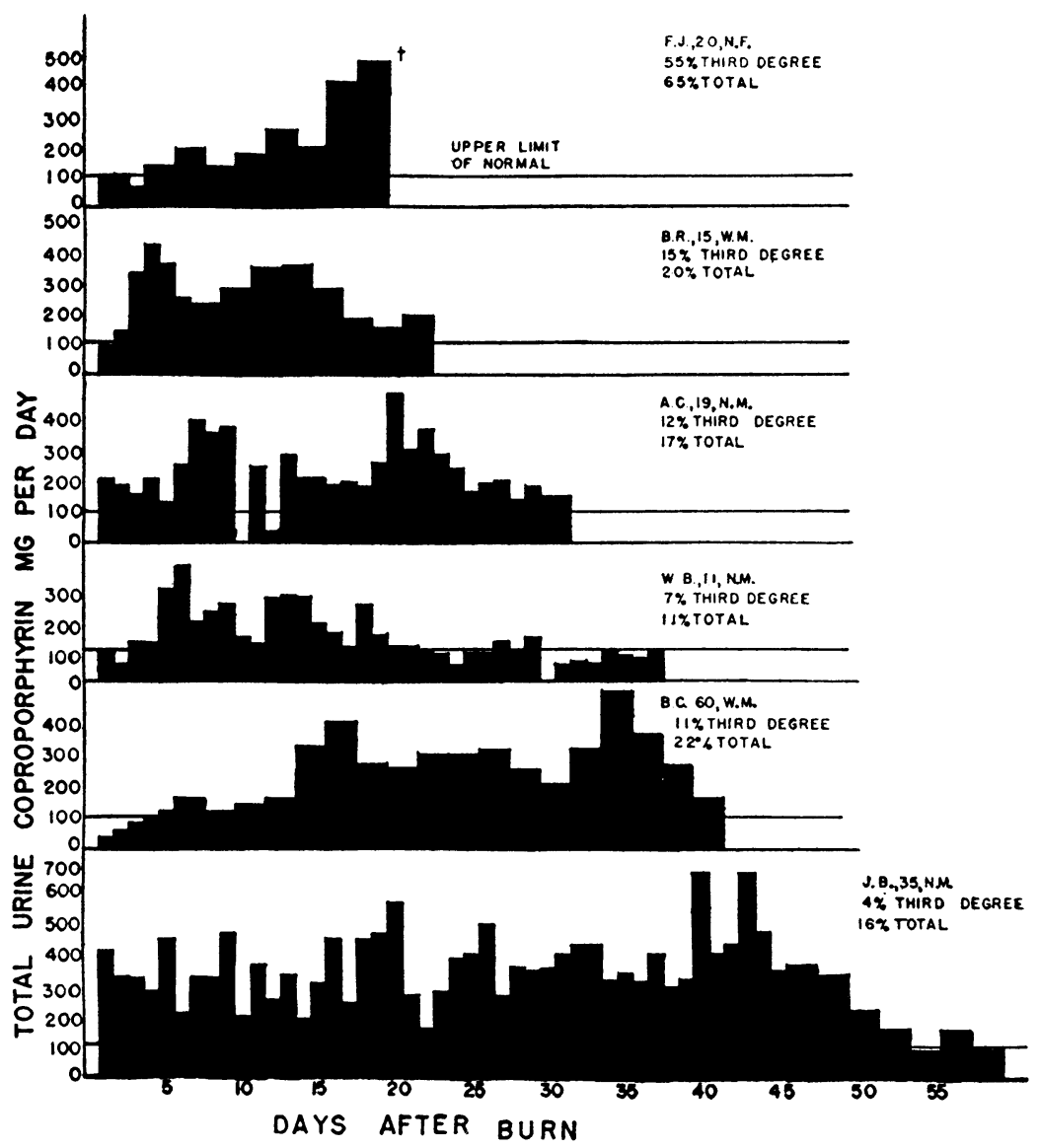

FIG. 6.

Urine coproporphyrin excretion was increased in six patients who showed varying amounts of third degree burns. High initial values were observed in two patients, A. C. and J. B. Aureomycin was administered to five of these patients with no observable effect on the coproporphyrin excretion, which returned to normal or near normal in five patients as healing was complete. F. J. expired on the 19th day.

values obtained upon admission became greatly elevated. In two others the values were greater than normal on admission and, therefore, may have resulted from some cause other than the burn. But in these patients the concentration increases over the admission value. Figure 6 shows the composite graph of the urine coproporphyrin in all patients. It was noted that in five of these patients (J. B., B. C., W. B., F. J., B. R.), oral aureomycin had no effect on the coproporphyrin excretion. Isomer analysis was not performed on any of these urines so that distribution of types cannot be determined. It would appear that the excretion of urinary coproporphyrin is the greatest during the convalescent phase and remains elevated until healing is almost complete.

Our study would make it appear that in the severely burned patient hemolysis must always be considered in the evaluation of the anemia and in the treatment of the early postburn phase. Even in the less severely burned patient hemolysis takes place. Brooks and his colleagues have demonstrated sludging of the red cells with subsequent agglutination and phagocytosis (21). Red cell destruction is associated with the opening of the porphyrin ring and subsequent degradation of hemoglobin to open chain tetrapyrroles. In our patients the drop in hemoglobin, the rise in hemolytic 
index, and often a rise in the indirect type of serum bilirubin are other experimental data to support this concept. In one severely burned patient there was evidence of hemolysis from admission to demise 32 days later.

In the study of the burn patient during convalescence and grafting, the ratio of the fecal urobilinogen to the total circulating hemoglobin would seem to point to decreased hemolytic activity, which may result from decreased hemoglobin synthesis. Actually the hemolytic index is lowered (W. B., Figure 5). Increased coproporphyrin excretion may also be a reflection of a disturbance in hemoglobin synthesis.

The synthesis component of the anemia of burns has been very thoroughly discussed by Moore and his associates (1) and they have used the method of estimating the uptake of radioactive iron as a guide in evaluating the marrow depression. One study showing a low fecal urobilinogen excretion, and hence hemoglobin catabolism, with low hemolytic indices in the convalescent phase, suggests a decreased breakdown (Figure 5). We believe that one of the most important factors in the apparent marrow depression is the presence of bacterial growth on the burned area. The urinary coproporphyrin studies during the convalescent phase may favor this idea. However, the urinary coproporphyrin findings may be evidence of liver malfunction.

Moore and his colleagues (1) described increases in urine urobilinogen in their patients, and our data is in agreement with their work. We interpret differently the increased quantity of urine urobilinogen even though there is an increased amount of fecal urobilinogen in the stool. The level of the urinary urobilinogen is probably a very sensitive index of liver cell function. In burns, what we are measuring by the urobilinogen excretion is not only evidence of hemolysis but also impairment of the ability of the liver to properly catabolize the increased amounts of this substance.

The present studies would seem to answer the question concerning the occurrence of hemolysis. We believe that hemolysis occurs extensively, particularly in the large burn, and must always be reckoned with in evaluating these patients. This study has not answered the second question entirely to our satisfaction. A continuous investigation of heme catabolism shows us there is a decreased breakdown of heme products during the convalescent phase of burns. It gives us very little insight into the mechanisms involved in this process. In severely burned patients, during the long convalescent phase there may be considerable hemolysis taking place as evidenced by an increased hemolytic index and an increased fecal urobilinogen. Increased breakdown coupled with a depressed bone marrow would make the anemia more severe. As our work has indicated in one patient, in spite of a repeated transfusion, anemia progressed rapidly.

No conclusion can be drawn about the effect of aureomycin as far as anemia of thermal burns is concerned, but we might draw some interesting speculation about urobilinogen metabolism and Ehrlich-reacting substances in the feces in patients who are receiving oral aureomycin. It would appear that aureomycin can effectively sterilize the gastro-intestinal tract, so that at least the main reduction agents of bilirubin are inhibited to such an extent that little or no reduction of bilirubin occurs. We, nevertheless, consistently found in the feces a small amount of Ehrlich-reacting substances. Whether these small quantities are separate and entirely different compounds from urobilinogen we are unable to say. We are tempted to think they may be other substances since, in patients in whom we expect large increases of urobilinogen, the detectible quantity of these compounds remains almost the same as that in patients who are excreting only an expected small amount of urobilinogen.

\section{CONCLUSIONS}

1. Hemolysis, as judged by fecal urobilinogen excretion compared to total circulating hemoglobin, occurs in burns of all degrees. It is very great in third degree burns of more than 20 per cent.

2. There is usually a constant increase in the urinary urobilinogen noted on the third day after injury and this probably denotes early hepatic dysfunction and inability to properly catabolize an increased amount of urobilinogen.

3. Oral aureomycin effectively reduces the fecal and urinary urobilinogen to very small amounts. It is questioned whether the petroleum ethersoluble Ehrlich-reacting substances found after oral aureomycin administration are urobilinogens or whether they are entirely different compounds. 
4. Additional evidence is presented to show that the anemia of thermal burns is at first hemolytic, then dyshemopoietic.

\section{REFERENCES}

1. Moore, F. D., Peacock, W. C., Blakeley, E., and Cope, O., Anemia of thermal burns. Ann. Surg., 1946, 124, 811.

2. Anderson, A. B., and Semeonoff, E., Chemical Changes in the Burned Patients; Studies of Burns and Scalds. Reports of the Burns Unit, Royal Infirmary, Glasgow, 1942-43, His Majesty's Stationary Office, London, 1945.

3. Shen, S. C., Ham, T. H., and Fleming, E. M., Studies on the destruction of red blood cells. III. Mechanism and complications of hemoglobinuria in patients with thermal burns: spherocytosis and increased osmotic fragility of red blood cells. New England J. Med., 1943, 229, 701.

4. Ham, T. H., Shen, S. C., Fleming, E. M., and Castle, W. B., Studies on the destruction of red blood cells. IV. Thermal injury: action of heat in causing increased spheroidicity, osmotic, and mechanical fragility, and hemolysis of erythrocytes: observations on the mechanisms of destruction of such erythrocytes in dogs and in a patient with a fatal thermal burn. Blood, 1948, 3, 373.

5. Brooks, F. H., Dragstedt, L. R., Warner, L., and Knisely, M. H., The sequence of circulatory changes following severe thermal burns. Anat. Record, 1948, 100, 644.

6. Cartwright, G. E., Lauritsen, M. A., Jones, P. J., Merrill, I. M., and Wintrobe, M. M., The anemia of infection. I. Hypoferremia, hypercupremia, and alterations in porphyrin metabolism in patients. J. Clin. Invest., 1946, 25, 65.

7. Saif, M. F., and Vaughan, J. M., The anemia associated with infection. J. Path. \& Bact., 1944, 56, 189.

8. Vaughan, J. M., and Saif, M. F., Haemoglobin metabolism in chronic infections. J. Path. \& Bact., 1939, 49, 69.

9. Miller, E. B., Singer, K., and Dameshek, W., Use of daily fecal output of urobilinogen and the hemolytic index in the measurement of hemolysis. Arch. Int. Med., 1942, 70, 722.
10. Wintrobe, M. M., Clinical Hematology. Lea \& Febiger, Philadelphia, 1946, 2nd edition.

11. Schwartz, S., Sborov, V., and Watson, C. J., Studies of urobilinogen. IV. The quantitative determination of urobilinogen by means of the Evelyn photoelectric colorimeter. Am. J. Clin. Path., 1944, 14, 598.

12. Schwartz, S., Hawkinson, V., Cohen, S., and Watson, C. J., A micromethod for the quantitative determination of the urinary coproporphyrin isomers (I and III). J. Biol. Chem., 1947, 168, 133.

13. Ducci, H., and Watson, C. J., The quantitative determination of the serum bilirubin with special reference to the prompt-reacting and chloroform-soluble types. J. Lab. \& Clin. Med., 1945, 30, 293.

14. Gregersen, M. I., A practical method for the determination of blood volume with the dye T-1824; a survey of the present basis of dye-method and its clinical applications. J. Lab. \& Clin. Med., 1944, $29,1266$.

15. Nachman, H. M., James, G. W., III, Moore, J. W., and Evans, E. I., A comparative study of red cell volumes in human subjects with radioactive phosphorus tagged red cell and T-1824 dye. J. Clin. Invest., 1950, 29, 258.

16. Lund, C. C., and Browder, N. C., The estimation of areas of burns. Surg., Gynec. \& Obst., 1944, 79, 352.

17. Wasserman, L. R., Volterra, M., and Rosenthal, N., Quantitative urobilinogen excretion following transfusion of fresh and stored blood. Am. J. Med. Sc., 1942, 204, 356.

18. Flink, E. B., and Skubi, K. B., Blood transfusion studies. II. The survival of fresh and stored blood transfused erythrocytes as determined by urobilinogen excretion. J. Lab. \& Clin. Med., 1946, 31, 1074.

19. London, I., West, R., Shemin, D., and Rittenberg, D., On the origin of bile pigment in normal man. J. Biol. Chem., 1950, 184, 351.

20. Sborov, V. M., Jay, A. R., and Watson, C. J., The effect of aureomycin on urobilinogen formation in the fecal flora. Proc. Central Soc. Clin. Research, 1949, 22, 70.

21. Brooks, F., Dragstedt, L. R., Warner, L., and Knisely, M. H., Sludged blood following severe thermal burns. Arch. Surg., 1950, 61, 387. 